\title{
Immunomodulatory properties of Alternanthera tenella Colla aqueous extracts in mice
}

R.N.M. Guerra ${ }^{1}$, H.-A.W. Pereira ${ }^{1}$,

L.M.S. Silveira ${ }^{2}$ and R.S.G. Olea ${ }^{3}$

\author{
${ }^{1}$ Laboratório de Imunofisiologia, Departamento de Patologia, \\ ${ }^{2}$ Departamento de Farmácia, and \\ 3Laboratório de Química de Produtos Naturais, Departamento de Química, \\ Universidade Federal do Maranhão, São Luís, MA, Brasil
}

\section{Correspondence \\ R.N.M. Guerra \\ Alameda Campinas, Quadra H, No. 1 Olho d'água \\ 65065-080 São Luís, MA \\ Brasil \\ Fax: +55-98-217-8501 \\ E-mail: rguerra@elo.com.br}

Presented at the XVII Annual Meeting of the Federação de Sociedades de Biologia Experimental, Salvador, BA, Brazil, August 28-31, 2002.

Research supported by the Universidade Federal do Maranhão and CNPq.

Received April 15, 2002 Accepted May 16, 2003

\begin{abstract}
Plants from the genus Alternanthera are thought to possess antimicrobial and antiviral properties. In Brazilian folk medicine, the aqueous extract of A. tenella Colla is used for its anti-inflammatory activity. The present study investigated the immunomodulatory property of $A$. tenella extract by evaluating the antibody production in male albino Swiss mice weighing 20-25 g (10 per group). The animals received standard laboratory diet and water ad libitum. The effect of A. tenella extract ( 5 and $50 \mathrm{mg} / \mathrm{kg}$, ip) was evaluated in mice immunized with sheep red blood cells (SRBC 10\%, ip) as T-dependent antigen, or in mice stimulated with mitogens $(10 \mu \mathrm{g}$, Escherichia coli lipopolysaccharide, LPS, ip). The same doses ( 5 and $50 \mathrm{mg} / \mathrm{kg}$, ip) of A. tenella extract were also tested for antitumor activity, using the Ehrlich ascites carcinoma as model. The results showed that $50 \mathrm{mg} / \mathrm{kg}$ A. tenella extract ip significantly enhanced $\operatorname{IgM}(64 \%)$ and $\operatorname{IgG} 2 \mathrm{a}(50 \%)$ antibody production in mice treated with LPS mitogen. The same dose had no effect on IgM-specific response, whereas the $5 \mathrm{mg} / \mathrm{kg}$ treatment caused a statiscally significant reduction of anti-SRBC IgM-specific antibodies (82\%). The aqueous extract of A. tenella $(50 \mathrm{mg} / \mathrm{kg})$ increased the life span (from $16 \pm 1$ to $25 \pm 1$ days) and decreased the number of viable tumor cells (59\%) in mice with Ehrlich ascites carcinoma. The present findings are significant for the development of alternative, inexpensive and perhaps even safer strategies for cancer treatment.
\end{abstract}

Key words

- Antitumor activity

- Antibody

- Immunomodulation

- Ehrlich ascites

- Alternanthera

.....................
Plants are invaluable sources of new drugs. There is an ever-growing interest in investigating different species of plants to identify their potential therapeutic applications. This increasing interest is due to a tremendous historical legacy in folk medicine use of plants as medicines (1) and their easy availability, cost effectiveness and pre- sumed safety. In the recent past, scientific studies on plants used in ethnomedicine have led to the discovery of many valuable drugs such as pilocarpine and vincristine among others.

Alternanthera tenella Colla (Amaranthaceae), a herbaceous plant commonly known as "enxuga" or "pérpetua do mato", is fre- 
quently found in northwest Brazil. A. tenella is used in folk medicine to treat fever, infections and genital inflammation (1). Some species of the Alternanthera genus have been reported to inhibit lymphocyte activation (2), to have antiviral (3) and hepatoprotective properties (4), antinociceptive effects, and analgesic activity (5). A. tenella was also found to have antibiotic activity in assays using Gram-positive or Gram-negative bacteria in vitro $(6,7)$.

The aim of the present study was to examine the immunological effect of $A$. tenella aqueous extracts in mice, with emphasis on antibody production and the antitumor activity.

Male albino Swiss mice weighing 20-25 $\mathrm{g}$ were used. The animals received standard laboratory diet (Purina chow, Campinas, SP, Brazil) and water ad libitum.

A. tenella aerial parts (stem and leaves) were locally collected (Horto Comunitário Jambeiro, São Luís, MA, Brazil). A voucher specimen (No. 1.160) identified by specialists at the Emilio Goeldi Museum, Belém, PA, Brazil, has been preserved in the Ático Seabra Herbarium, Universidade Federal do Maranhão, São Luís, MA, Brazil.

The fresh aerial parts of A. tenella $(350 \mathrm{~g})$ were dried and powdered and the aqueous extract was prepared by the addition of 700 $\mathrm{ml}$ twice-distilled water. The crude extract was then concentrated in a rotary evaporator $\left(40^{\circ} \mathrm{C}\right.$ under vacuum) and the resulting extract dissolved to a final concentration of 10 $\mathrm{mg} / \mathrm{ml}$ in saline solution $(0.87 \% \mathrm{NaCl})$.

For the antibody assays, A. tenella extract was injected intraperitoneally (ip) in two different doses (5 and $50 \mathrm{mg} / \mathrm{kg}$ ) $48 \mathrm{~h}$ before immunization with sheep red blood cells (SRBC, $0.5 \mathrm{ml}$ of a $10 \%$ saline suspension) or $48 \mathrm{~h}$ before ip stimulation of the animals with $10 \mu \mathrm{g}$ of Escherichia coli lipopolysaccharide (LPS; Sigma, St. Louis, MO, USA).

Spleen cells were obtained from whole spleens either 5 days after immunization with SRBC, or 2 days after stimulation with E. coli $\mathrm{LPS}$ ( $\mathrm{N}=10$ mice/group). The cell suspension obtained was washed three times in balanced salt solution prepared as previously described (8).

Spleen cells $\left(10^{6}\right)$ were plated with $25 \mu \mathrm{l}$ SRBC or SRBC conjugated to protein A (Sigma). Fifty microliters of guinea pig serum, $250 \mu \mathrm{l}$ of bacto-agar (Difco Laboratories, Detroit, MI, USA) and $25 \mu \mathrm{l}$ of goat anti-mouse IgM or IgG2a antibody (Sigma) were also added. After 4-h incubation at $37^{\circ} \mathrm{C}$ and $18-\mathrm{h}$ incubation at $4^{\circ} \mathrm{C}$ the number of antibody-secreting cells was determined (8). For each stimulation, three experiments were performed.

Antitumor activity was assessed by treating the mice with the extract before the ip injection of Ehrlich ascites carcinoma cells.

Ehrlich ascites cells were maintained as tumors in the peritoneal cavity of Swiss albino mice obtained from the Central Animal House of Universidade Federal do Maranhão. For the experimental procedures, $5 \mathrm{ml}$ of ascitic fluid from mice inoculated 8 days before was collected and centrifuged at 140 $g$ for $10 \mathrm{~min}$. Male Swiss albino mice weighing 20-25 g (10 per group) were injected with $10^{6}$ tumor cells ip for the induction of ascites tumor $48 \mathrm{~h}$ after $A$. tenella extract treatment ( 5 or $50 \mathrm{mg} / \mathrm{kg}$ body weight, ip) and a control group treated only with saline was used for comparison. The effects of $A$. tenella on tumor growth and host survival were estimated by peritoneal tumor cell count, animal weight, and percent increase in life span of the tumor hosts ( $\mathrm{N}=10$ mice/group). The Trypan blue exclusion test was used to determine the percentage of living cells, which were counted in a Neubauer chamber. Cell viability was always found to be $90 \%$ or higher.

Results are reported as means \pm SEM for plaque-forming cell results and as means \pm SD for cancer studies. Statistical analyses were carried out by the Student $t$-test and the difference was considered statiscally signifi- 
cant when $\mathrm{P}<0.05$.

Mice treated with the lower dose of $A$. tenella extract $(5 \mathrm{mg} / \mathrm{kg}) 48 \mathrm{~h}$ before immunization showed a significant reduction in anti-SRBC IgM-secreting cells when compared to control (from $1730 \pm 354$ to $310 \pm$ 51). In contrast, the higher dose of the same extract $(50 \mathrm{mg} / \mathrm{kg})$ had no significant effect (from $1730 \pm 354$ to $1480 \pm 185$ ) on plaqueforming cell numbers compared to control (Figure 1A).

In mice stimulated with LPS, only the higher dose $(50 \mathrm{mg} / \mathrm{kg})$ of $A$. tenella extract significantly enhanced IgM and IgG2a antibody production compared to control (from $103 \pm 15$ to $284 \pm 19$ and from $106 \pm 15$ to $209 \pm 22$, respectively), whereas the lower dose had no effect (from $103 \pm 15$ to $128 \pm$ 10 and from $106 \pm 15$ to $111 \pm 14$, respectively) (Figure 1B). No statistically significant differences between $A$. tenella-treated animals and controls were observed in total numbers of nucleated spleen cells or spleen weight.

The present experiments revealed a strong dose-dependent effect of $A$. tenella extract on antibody production in the spleen. A low dose of plant extract significantly inhibited IgM antibody production in mice immunized with SRBC, suggesting that the extract contains substance(s) with an inhibitory action on B lymphocyte function.

At a higher concentration $(50 \mathrm{mg} / \mathrm{kg})$, however, the same aqueous extract of $A$. tenella enhanced IgM and IgG2a antibody production in mice stimulated with $E$. coli LPS. These results suggest that the aqueous extract of A. tenella was able to reduce antibody production to T-dependent antigen. In addition, the extract can exert a stimulatory effect on antibody production induced by the mitogens. The nature of the substance(s) responsible for these effects is unknown. Isolation and purification of the components present in the A. tenella extract are needed to characterize the nature of the active compound(s).
An immunosuppressive and immunostimulatory activity for the same compound was previously described by Wagner and Proksch (9) when they studied the biological activity of tylophorin isolated from Tylophora indica necasthmatica. Extracts of a diverse range of plants have been shown to possess immunomodulatory properties by presenting simultaneous immunostimulatory and immunosuppressive effects (10-12).

The effect of A. tenella extract (5 or 50 $\mathrm{mg} / \mathrm{kg}$ body weight, $i p$ ) on the survival time of Ehrlich ascites carcinoma-bearing mice is summarized in Figure 2A. The mean survival time was $16 \pm 1$ days for the Ehrlich ascites carcinoma control group, $20 \pm 2$ days for the $5 \mathrm{mg} / \mathrm{kg}$ group and $25 \pm 1$ days for the $50 \mathrm{mg} / \mathrm{kg}$ group (Figure 2A). The viable tumor cell count was significantly inhibited only in the $50 \mathrm{mg} / \mathrm{kg}$ group (Figure 2B). This inhibition was 59\% compared to the control and $62 \%$ compared to the $5 \mathrm{mg} / \mathrm{kg}$ group. No variation in animal weight was observed
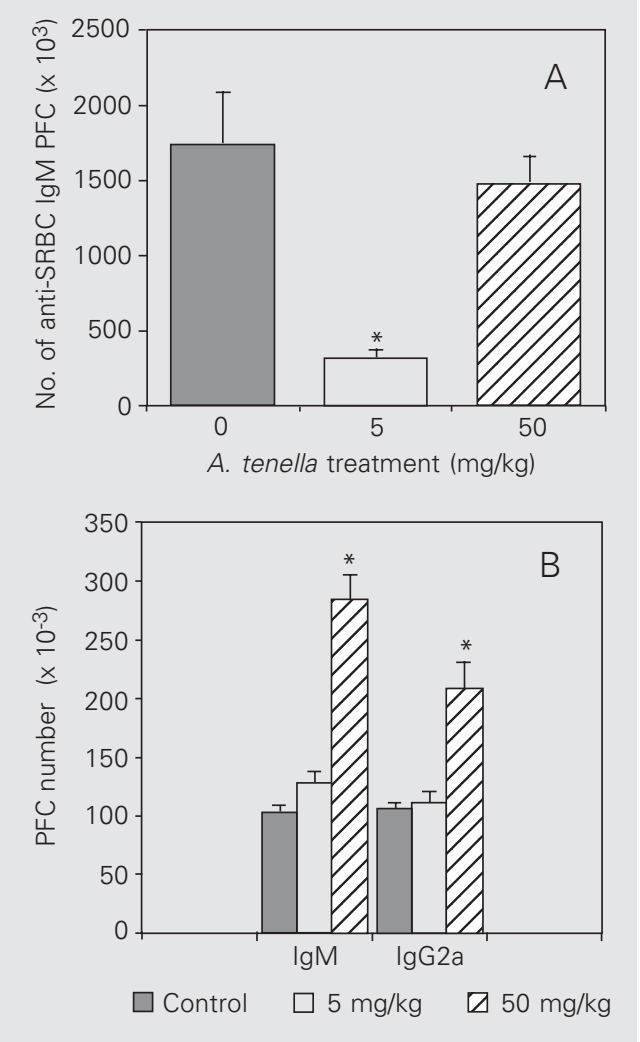

Figure 1. Effect of Alternanthera tenella extract ( 5 and $50 \mathrm{mg} / \mathrm{kg}$ ) on $\lg \mathrm{M}$ and $\lg \mathrm{G} 2 \mathrm{a}$ production assayed by the plaque-forming cell (PFC) assay. A, Mice immunized with sheep red blood cells (SRBC), and $B$, mice treated with $10 \mu \mathrm{g}$ LPS $48 \mathrm{~h}$ after $A$ tenella treatment. Data are reported as means \pm SEM for 10 animals. ${ }^{*} \mathrm{P}<0.001$ compared to control (Student $t$-test). 
Figure 2. Effect of Alternanthera tenella extract ( 5 and $50 \mathrm{mg} / \mathrm{kg}$ ) on Ehrlich tumor development when given $48 \mathrm{~h}$ before tumor cell inoculation $\left(10^{6}\right)$. A, Survival of tumor-bearing mice treated with $A$. tenella extract. $B$, Reduction in total number of tumor cells recovered from the peritoneal cavity. $C$, Mean daily weight of $A$. tenella-treated and control animals. Data are reported as means \pm SD for 10 animals per group. ${ }^{*} P<0.05$ compared with control (Student $t$-test). until 8 days after tumor inoculation when the weight of the $5 \mathrm{mg} / \mathrm{kg}$ group was significantly lower than the control (Figure 2C).

The present study demonstrated that the aqueous extract of $A$. tenella also has a tumor inhibitory activity on Ehrlich ascites cells. Furthermore, the increase in life span of tumor-bearing mice caused by A. tenella treatment is a positive result, since the plant extract demonstrated an increased survival time effect even in groups whose tumor cell counts were not significantly reduced. The exact mechanism by which $A$. tenella medi-
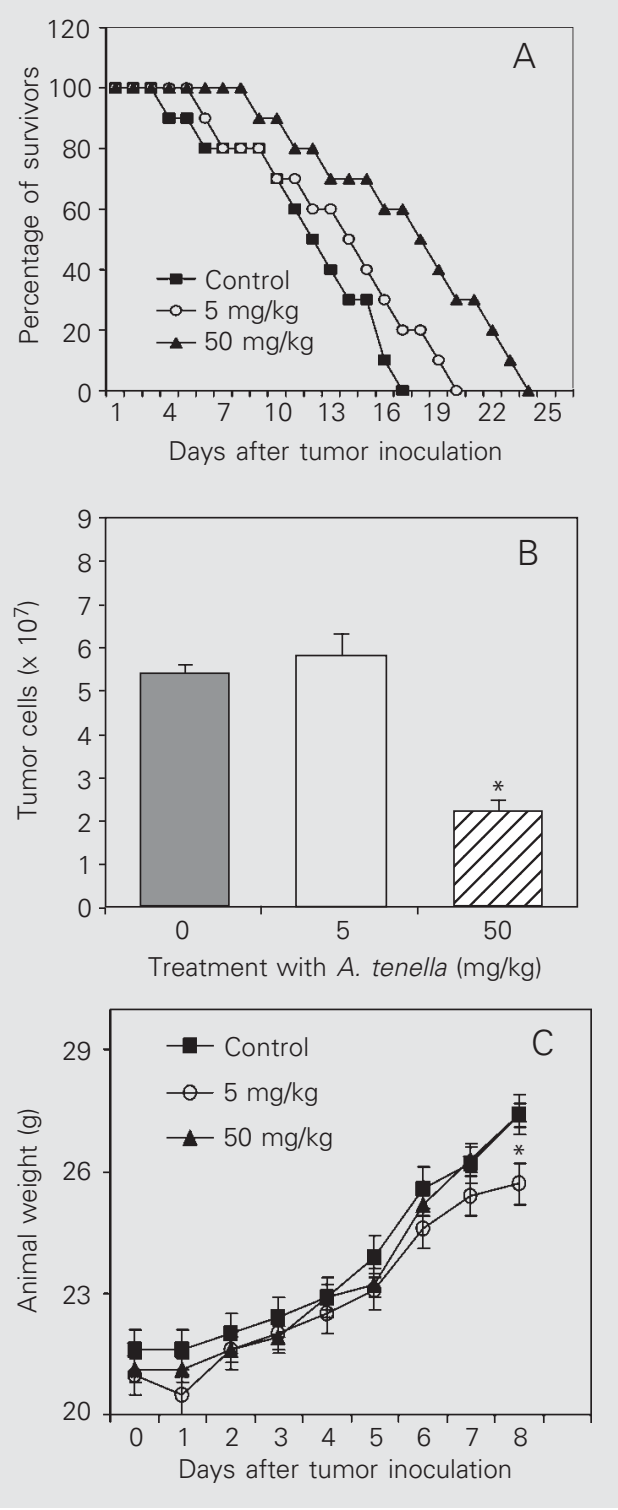

ates its antitumor effect is not known.

Some compounds with an immunomodulatory activity like fatty acids (10), flavonoids $(12,13)$, polysaccharides $(14,15)$, and triterpenes (16) are also found in the Alternanthera genus (3-5,7,17). Most studies concerning the immunomodulatory activities of plants have been carried out using crude extracts $(11,16)$. In some, combinations of various herbs or herbs in combination with minerals have been used taking into consideration Ayurvedic (12), Unani (17) or Chinese (18) traditional formulations. Although it may be rational to use a single plant or its single constituents, it has been a general experience that the total plant extract shows more efficacy compared to single constituents (18).

The present findings are significant for the development of alternative, inexpensive and perhaps even safer strategies for cancer treatment. Although in this study the $A$. tenella extract was more effective in inducing a reduction in the total number of tumor cells (Figure 2B) than in prolonging the life of tumor-bearing animals, the finding that $A$. tenella groups presented an increased life span when compared to control (Figure 2A) might be considered a relevant observation for the eventual development of new strategies for the treatment of some forms of cancer. It is also important to note that the beneficial effect was observed with a low concentration of crude extract $(5 \mathrm{mg} / \mathrm{kg})$, in contrast to the high concentrations of plant extracts employed in other experiments (100, 200 and $300 \mathrm{mg} / \mathrm{kg}$ (Ref. 19) or 250 and 500 $\mathrm{mg} / \mathrm{kg}$ (Ref. 20)) dealing with tumor growth inhibition in mice $(15,19,20)$.

A. tenella extract seems to have the potential to interfere with the process of immune activation either by inhibiting or stimulating antibody production, depending on its concentration, and also by potentially reducing the number of tumor cells. The bi-directional effect of $A$. tenella Colla extract observed in this study is of high interest if we 
consider that $A$. tenella can act in a prostimulatory manner on lymphocytes, as shown after stimulation with a mitogen. In contrast, A. tenella had an up-regulating effect after immunization with T-dependent antigens.

The present results support the hypothesis that water-soluble components derived from $A$. tenella may have an important effect on the immune system of mice, indicating that plant extracts are able to effectively modulate immunological interactions. This finding is of special interest since the biologically active compounds seem to be highly soluble in aqueous solution.

\section{Acknowledgments}

\section{We thank Carolina Guerra Libério, Dr.} Flavia Raquel Fernandes do Nascimento and Dr. Talapala G. Naidu for helpful suggestions.

\section{References}

1. Rêgo TJA (1995). Fitogeografia das Plantas Medicinais no Maranhão. 2nd edn. EDUFMA, São Luís, MA, Brazil, 108-109.

2. Moraes VLG, Santos LFM, Castro SB, Loureiro LH, Lima AO, Souza MLM, Yien LMK, Rossi-Bergmann B \& Costa SS (1994). Inhibition of lymphocyte activation by extracts and fractions of Kalanchoe, Alternanthera, Paullinia and Mikania species. Phytomedicine, 1: 199-204

3. Lagrota MHC, Wiggs MD, Miranda MMFS, Camara FP, Couceiro JNSS \& Costa SS (1994). Inhibitory activity of extracts of Alternanthera brasiliana (Amaranthaceae) against Herpes simplex virus. Phytotherapy Research, 8: 358-361.

4. Lin SC, Lin YH, Shyuu SJ \& Lin CC (1994). Hepatoprotective effects of Taiwan folk medicine - Alternanthera sessilis on liver damage induced by various hepatotoxins. Phytotherapy Research, 8: 391398.

5. Macedo AF, Barbosa NC, Esquibel MA, Souza MN \& Cechinel-Filho $V$ (1999). Pharmacological and phytochemical studies of callus culture extracts from Alternanthera brasiliana. Pharmazie, 54: 776-777.

6. Gallegos Olea RS, Silveira LMS, Oliveira AV, Mendes AMC \& Carvalho LCF (2000). Atividade antibacteriana de frações polares de partes aéreas de Alternanthera tenella Colla (Amaranthaceae). XVI Simpósio de Plantas Medicinais do Brasil, Recife, PE, Brazil, Abstract 124.

7. Silveira LMS (2000). Caracterização fitoquímica, biológica e mineral de partes aéreas de Alternanthera tenella Colla (Amaranthaceae). Master's thesis, Universidade Federal do Maranhão, São Luís, MA, Brazil.

8. Bernabé R, Tuneskog M, Martinez CA \& Coutinho A (1981). The protein A plaque assay for detection of immunoglobulin secreting cells. Journal of Immunological Methods, 9: 187-198.

9. Wagner $H$ \& Proksch A (1985). Immunostimulatory drugs of fungi and higher plants. In: Wagner $\mathrm{H}$, Hirino $\mathrm{H}$ \& Farnsworth NR (Editors), Economic and Medicinal Plant Research. Vol. 1. Academic Press Inc., London, 113-153.

10. Mediratta PK, Sharma KK \& Singh S (2002). Evaluation of immuno- modulatory potential of Ocimum sanctum seed oil and its possible mechanism of action. Journal of Ethnopharmacology, 80: 15-20.

11. Yamaguchi H (1992). Immunomodulation by medicinal plants. Advances in Experimental Medicine and Biology, 319: 287-297.

12. Ziaudidin M, Phansaklar N, Patki P, Diwanay S \& Patwardhan B (1996). Studies on the immunomodulatory effect of Ashwagandha. Journal of Ethnopharmacology, 50: 69-76.

13. Middleton Jr E (1998). Effect of plant flavonoids on immune and inflammatory cell function. Advances in Experimental Medicine and Biology, 439: 175-182.

14. Hase K, Basnet P \& Kadota I (1996). Immunostimulatory activity of Celosian, an antihepatotoxic polysaccharide isolated from Celosia argentea. Planta Medica, 63: 216-219.

15. Wong CK, Leung KN \& Fung KP (1994). Immunomodulatory and anti-tumor polysaccharides from medicinal plants. Journal of International Medical Research, 22: 299-312.

16. Souza MM, Kern P, Floriani AEO \& Cechinel-Filho V (1998). Analgesic properties of a hydroalcoholic extract obtained from Alternanthera brasiliana. Phytotherapy Research, 12: 279-281.

17. Bajaj S, Ahmad I, Fatima M, Raisuddin S \& Vohora SB (1999). Immunomodulatory activity of a Unani gold preparation used in Indian system of medicine. Immunopharmacology and Immunotoxicology, 21: 151-161.

18. Nakai S, Kawakita T, Zhou N, Matsuura K, Oka M, Nagasawa $H_{\text {, }}$ Saito Y, Suzuki A, Himeno K \& Nomoto K (1993). Treatment effect of a traditional Chinese medicine, Ren-shen-yang-rong-tang (Japanese name: Ninjinyouei-to), on autoimmune MRL:MP-Ipr./pr mice. International Journal of Immunopharmacology, 15: 589-596.

19. Gupta M, Mazumder UK, Rath N \& Mukhopadhyay DK (2000). Antitumor activity of methanolic extract of Cassia fistula L. seed against Ehrlich ascites carcinoma. Journal of Ethnopharmacology, 72: 151156.

20. Jose JK, Kuttan G \& Kuttan R (2001). Anti-tumor activity of Emblica officinalis. Journal of Ethnopharmacology, 75: 65-69. 